University of Nebraska - Lincoln

DigitalCommons@University of Nebraska - Lincoln

Faculty Papers and Publications in Animal

Science

Animal Science Department

2003

\title{
Prerigor Injection Using Glycolytic Inhibitors in Low-Quality Beef Muscles
}

N. C. Jerez

University of Nebraska-Lincoln

Chris R. Calkins

University of Nebraska-Lincoln, ccalkins1@unl.edu

J. Velazco

Instituto Tecnolo'gico y Estudios Superiores de Monterrey, Mexico

Follow this and additional works at: https://digitalcommons.unl.edu/animalscifacpub

Part of the Animal Sciences Commons

Jerez, N. C.; Calkins, Chris R.; and Velazco, J., "Prerigor Injection Using Glycolytic Inhibitors in Low-Quality Beef Muscles" (2003). Faculty Papers and Publications in Animal Science. 585.

https://digitalcommons.unl.edu/animalscifacpub/585

This Article is brought to you for free and open access by the Animal Science Department at DigitalCommons@University of Nebraska - Lincoln. It has been accepted for inclusion in Faculty Papers and Publications in Animal Science by an authorized administrator of DigitalCommons@University of Nebraska - Lincoln. 


\title{
Prerigor injection using glycolytic inhibitors in low-quality beef muscles ${ }^{1}$
}

\author{
N. C. Jerez*, C. R. Calkins ${ }^{* 2}$, and J. Velazco $\dagger$ \\ *Department of Animal Science, University of Nebraska, Lincoln 68583-0908 and \\ $\dagger$ Instituto Tecnológico y Estudios Superiores de Monterrey, México
}

\begin{abstract}
The objective of this experiment was to determine the effect of prerigor injection of several glycolytic inhibitors on $\mathrm{pH}$, color, tenderness, and related traits of low-value beef cuts. The semimembranosus, triceps brachii, and supraspinatus muscles from each of 10 steer carcasses were removed $1 \mathrm{~h}$ postmortem. Control samples remained in the carcass at $2^{\circ} \mathrm{C}$ for $24 \mathrm{~h}$. Prerigor muscles were injected and tumbled with $10 \%$ (by weight) of one of four solutions: sodium citrate $(\mathrm{NaC} ; 200 \mathrm{mM})$, sodium fluoride $(\mathrm{NaF} ; 200 \mathrm{mM})$, sodium acetate $(\mathrm{NaA} ; 200 \mathrm{mM})$, and calcium chloride $\left(\mathrm{CaCl}_{2} ; 300 \mathrm{mM}\right)$. All muscles treated with $\mathrm{NaC}$ and
\end{abstract}

$\mathrm{NaF}$ showed the highest $\mathrm{pH}$ and glycogen content $(P<$ 0.05 ), indicating that glycolysis was inhibited. Injection of $\mathrm{NaC}$ in semimembranosus and supraspinatus produced the tenderest meat $(P<0.05)$, showing a greater increase in tenderization at $3 \mathrm{~d}$ than at $7 \mathrm{~d}$ postmortem. Treatment did not affect color or oxidation-reduction potential, but all treated muscles tended to be more oxidative (higher oxidation-reduction potential). Sodium citrate was identified as a potential compound to enhance tenderness of prerigor muscle without altering color. Further studies are required to investigate its effect on palatability traits and to provide a basis for commercial application of the process.

Key Words: Beef, Glycolysis, Inhibitors, Tenderness

(c)2003 American Society of Animal Science. All rights reserved.

J. Anim. Sci. 2003. 81:997-1003

\section{Introduction}

Tenderness is the organoleptic trait that most affects consumer acceptance of beef, whereas lean color is the most important attribute at point of purchase (Faustman and Cassens, 1991). Brooks et al. (2000) concluded from the 1998 National Beef Tenderness Survey that muscles from the round and chuck in particular need improvement in tenderness. Treatments to improve tenderness of chuck and round muscles would add value to the whole carcass.

Postmortem time, temperature, and rate of glycolysis can affect the attributes of meat products, especially products made from hot-boned meat. Muscle $\mathrm{pH}$ affects beef tenderness; high-pH muscle is tenderer than normal pH muscle (Harrell et al., 1978; Beltrán et al., 1997). However, high-pH meat is quite dark and suffers severe loss in value as a consequence. Color has been associated with tenderness as well. Wulf et al. (1997) reported that dark-cutting beef (which has a higher $\mathrm{pH}$

\footnotetext{
${ }^{1}$ Published as paper No. 13036, Journal Series, Nebraska Agric. Res. Div., University of Nebraska, Lincoln. The authors thank S. Kachman for the helpful assistance on the statistical analysis.

${ }^{2}$ Correspondence: A213 Animal Sciences, P.O. Box 830908 (phone: 402-472-6314; fax: 402-472-6362; E-mail: ccalkins1@unl.edu).

Received June 19, 2000.

Accepted November 21, 2002.
}

than normal) is less tender. Conversely, Jeremiah et al. (1991) stated that beef carcasses with dark color produce more tender steaks.

Biochemical manipulation of postmortem glycogen breakdown may offer the potential to enhance tenderness. The inhibition of glycolysis prevents lactic acid formation, consequently maintaining a high $\mathrm{pH}$, which may increase tenderness and water-holding capacity (WHC). Many glycolytic inhibitors have been identified; however, the effects of these inhibitors on meat quality traits are unknown. This study investigated the effects of prerigor injection of four different compounds on $\mathrm{pH}$, tenderness, color, and related traits of low-value beef cuts.

\section{Materials and Methods}

Ten steers (22- to 24 -mo-old, 515 to $676 \mathrm{~kg}$ live weight) were slaughtered at the University of Nebraska Meat Laboratory. Prerigor semimembranosus (from the round), triceps brachii and supraspinatus muscles (from the chuck) were excised, after evisceration (approximately $1 \mathrm{~h}$ postmortem), from both sides of the carcass. Twenty muscles of each muscle type were randomly assigned to each of the treatments: control (remained in the carcass at $2^{\circ} \mathrm{C}$ for $24 \mathrm{~h}$ ), sodium citrate $(\mathrm{NaC} ; 200 \mathrm{mM})$, sodium fluoride $(\mathrm{NaF} ; 200 \mathrm{mM})$, sodium acetate $(\mathrm{NaA} ; 200 \mathrm{mM})$, and calcium chloride $\left(\mathrm{CaCl}_{2}\right.$; 
$300 \mathrm{mM}$ ). Treatments and levels were identified in preliminary experiments (Calkins et al., 1999). Calcium chloride was included because it has been shown to enhance tenderness (Koohmaraie et al., 1988; 1990; Wheeler et al., 1994). The other compounds demonstrated the potential to inhibit glycolysis and/or enhance tenderness with minimal effects on color (Calkins et al., 1999). Each muscle was injected by hand with a five-needle ham injection unit with a volume equal to $8 \%$ of the muscle weight at $2 \mathrm{~h}$ postmortem. Each muscle was then individually vacuum-packaged with an additional $2 \%$ of solution (to complete $10 \%$ of muscle weight) and tumbled in a 34-kg-capacity tumbler (Röschermatic, Oshabrück, Germany) for $30 \mathrm{~min}$.

Samples of each muscle (approximately $100 \mathrm{~g}$ ) were obtained at 24 and $72 \mathrm{~h}$ after injection for determination of $\mathrm{pH}$, oxidation-reduction potential, glycogen content, $\mathrm{R}$-value, and $\mathrm{NAD}^{+} / \mathrm{NADH}$. The samples were frozen immediately in liquid nitrogen and stored at $-80^{\circ} \mathrm{C}$ until they were powdered and analyzed. Fresh muscle samples (approximately $20 \mathrm{~g}$ ) were obtained at $72 \mathrm{~h}$ after injection and assayed immediately for $\mathrm{WHC}$ and sarcomere length.

\section{Analytical Methods}

One 2.54-cm-thick steak from each muscle was cut and frozen after 3 and $7 \mathrm{~d}$ postmortem for WarnerBraztler shear force determination. Steaks were broiled on Farberware Open Hearth broilers (model 350A, Walter Kidde, Bronx, NY) to a final internal temperature of $70^{\circ} \mathrm{C}$ (AMSA, 1995). Temperature was monitored using an Omega thermocouple thermometer type $\mathrm{T}$ (Omega Engineering, Inc., Stamford, CT) inserted into the geometric center of each steak. The cooked steaks were chilled $2 \mathrm{~h}$ at $2^{\circ} \mathrm{C}$, and then eight cores $(1.27 \mathrm{~cm}$ in diameter) were removed parallel to the muscle fiber orientation. Cores were sheared once each on an Instron Universal Testing Machine (model 55R1123, Instron Corp., Canton, MA) with a Warner-Bratzler attachment and $250-\mathrm{mm} / \mathrm{min}$ crosshead speed.

Muscle $\mathrm{pH}$ was determined by homogenizing (Polytron, Brinkman Instruments, New York, NY) $5 \mathrm{~g}$ of frozen, powdered samples in $50 \mathrm{~mL}$ of water. Measurements were obtained with an Orion model SA $720 \mathrm{pH}$ meter (Orion Research, Inc., Boston, MA) fitted to a Corning general-purpose electrode (Corning Glass Works, Corning, NY).

Oxidation-reduction potential was measured in duplicate. Ten grams of frozen, powdered sample was weighed into a Waring blender cup and blended with $0.1 M$ phosphate buffer ( $\mathrm{pH}$ 6.0) using a vacuum pump to minimize oxygen incorporation. Absolute oxidationreduction potential readings were taken after a 2-min equilibration with an oxidation-reduction combination electrode \#406080 (Corning Glass Works) attached to a pH meter (Orion Model SA $720 \mathrm{pH}$ meter).

Sarcomere length was measured at $72 \mathrm{~h}$ postmortem on fresh muscle samples using the neon laser diffraction method described by Cross et al. (1981) using a 5-mW helium-neon laser light at $632.8 \mathrm{~nm}$ (Melles Griot, Carlsbad, CA).

A Hunter Lab Mini Scan XE Plus model No. O-L (Hunter Associates, Reston, VA) was used with a 2.5$\mathrm{cm}$ open port, Illuminant $\mathrm{A}$, and $2^{\circ}$ standard observer to evaluate color objectively at 24 and $72 \mathrm{~h}$ postinjection. Three readings were obtained from the muscle surface and the mean was calculated. Readings were obtained at 24 and $72 \mathrm{~h}$ after exposing muscles to air for 30 min (bloom). The $L^{*}, a^{*}$, and $b^{*}$ values were taken as indicators of lightness, redness, and yellowness, respectively.

Water-holding capacity was measured at $72 \mathrm{~h}$ postmortem on fresh muscle following the centrifugation method described by Jauregui et al. (1981). Three pieces of Whatman \#3 filter paper and one piece of Whatman \#50 filter paper folded into a thimble shape were weighed before and after the addition of $1.5 \pm 0.3 \mathrm{~g}$ of muscle sample and centrifugation at $30,000 \times g$. Waterholding capacity was expressed as percentage of weight loss from the original sample.

Glycogen was extracted from $3 \mathrm{~g}$ of frozen, powdered samples (in duplicate), which were homogenized with $15 \mathrm{~mL}$ of $0.6 \mathrm{~N}$ perchloric acid. Amyloglucosidase from Aspergillus niger (No. A3514, Sigma Chemical, St. Louis, MO) was used to hydrolyze the glycogen to free glucose following the method described by Roehrig and Allred (1974). The enzymatic assay for glucose was as described by Dalrymple and Hamm (1973), using glucose-6-phosphate dehydrogenase (No. G8878, Sigma Chemical) and hexokinase (No. H5500, Sigma Chemical) enzymes. The muscle glycogen content was expressed as $\mu \mathrm{mol}$ glucose/g muscle.

The R-value was determined as described by Honikel and Fischer (1977). Frozen, powdered samples (4 g) were homogenized with $10 \mathrm{~mL}$ of $0.9 \mathrm{M}$ perchloric acid. The absorption at 250 and $260 \mathrm{~nm}$ was measured with phosphate buffer as a blank and the R-value (Abs 250/ Abs 260) was calculated.

Nicotinamide adenine dinucleotides $\left(\mathrm{NAD}^{+}\right.$and $\mathrm{NADH}$ ) were determined by the enzymatic method of Klingenberg (1985). For NAD extraction, $1 \mathrm{~g}$ of frozen, powdered sample was mixed with $5 \mathrm{~mL}$ of $0.6 \mathrm{~N}$ perchloric acid and centrifuged for $5 \mathrm{~min}$ at 3,000 $\times \mathrm{g}$. Extraction of NADH was performed mixing $2 \mathrm{~mL}$ of $0.5 \mathrm{~N}$ cold alcoholic potassium hydroxide solution with 200 to 300 $\mathrm{mg}$ of frozen tissue with a magnetic stirrer. Neutralization of $\mathrm{NAD}^{+}$extracts was with $1 \mathrm{~N} \mathrm{KOH}$ and neutralization of NADH extracts was with $0.5 M$ triethanolamineHCL-phosphate buffer. The $\mathrm{NAD}^{+}$and $\mathrm{NADH}$ concentrations were determined by following the change in absorbance due to addition of alcohol dehydrogenase (No. A3263, Sigma Chemical) for $\mathrm{NAD}^{+}$reduction or lactate dehydrogenase (No. L5432, Sigma Chemical) for NADH oxidation. Results were expressed as $\mu \mathrm{mol} /$ $\mathrm{g}$ of muscle. 
Table 1. Effect of treatment on water holding capacity and color $(n=12)$

\begin{tabular}{lcccc}
\hline \hline Treatment & WHC $^{\mathrm{a}}$ & L*value $^{\mathrm{b}}$ & $\mathrm{a}^{*}$ value $^{\mathrm{c}}$ & $\mathrm{b}^{*}$ value $^{\mathrm{d}}$ \\
\hline Control $^{\mathrm{e}}$ & $37.38^{\mathrm{h}}$ & $28.6^{\mathrm{i}}$ & $26.1^{\mathrm{h}}$ & $6.66^{\mathrm{h}}$ \\
Calcium chloride $^{\mathrm{f}}$ & $39.50^{\mathrm{h}}$ & $29.50^{\mathrm{hi}}$ & $25.1^{\mathrm{h}}$ & $6.69^{\mathrm{h}}$ \\
Sodium acetate $^{\mathrm{g}}$ & $37.56^{\mathrm{h}}$ & $31.23^{\mathrm{h}}$ & $22.7^{\mathrm{i}}$ & $6.26^{\mathrm{h}}$ \\
Sodium fluoride $^{\mathrm{g}}$ & $34.36^{\mathrm{i}}$ & $27.80^{\mathrm{i}}$ & $21.4^{\mathrm{i}}$ & $5.87^{\mathrm{i}}$ \\
Sodium citrate $^{\mathrm{g}}$ & $37.90^{\mathrm{hi}}$ & $29.42^{\mathrm{hi}}$ & $22.6^{\mathrm{i}}$ & $6.04^{\mathrm{i}}$ \\
Standard deviation $^{\mathrm{n}}$ & 0.97 & 0.60 & 0.6 & 0.15 \\
\hline
\end{tabular}

${ }^{\mathrm{a}} \mathrm{WHC}=$ water-holding capacity expressed as percentage of weight lost from original sample.

${ }^{\mathrm{b}} \mathrm{L}^{*}$ value $=$ lightness; $100=$ white, $0=$ black.

$\mathrm{c}^{\mathrm{a}} *$ value $=$ redness; $-80=$ green, $100=$ red.

${ }^{\mathrm{d}} \mathrm{b} *$ value $=$ yellowness $;-50=$ blue, $70=$ yellow .

${ }^{\mathrm{e}}$ Muscles remained in the carcass at $2{ }^{\circ} \mathrm{C}$ for $24 \mathrm{~h}$.

${ }^{f}$ Concentration: $300 \mathrm{~m} M$.

gConcentration: $200 \mathrm{mM}$.

h,i Means bearing the same letters within a column are not significantly different $(P<0.05)$

\section{Statistical Analysis}

Data were analyzed by ANOVA (SAS Inst., Inc., Cary, NC) for a factorially arranged split-split-plot design with muscle as the whole plot treatment, injection as the split-plot treatment, and time as the split-split-plot treatment (repeated measures). Animal $\times$ muscle was the whole plot error term, and animal $\times$ muscle $\times$ side was the split-plot error term. Mean separation for a significant effect was accomplished with the PDIFF option of the least squares procedures of SAS adjusted by Tukey (Steel and Torrie, 1980). Water-holding capacity and sarcomere length data were only evaluated at 72 $\mathrm{h}$ postmortem, therefore time was excluded from the model for these traits.

\section{Results}

The ANOVA showed significant effects of treatment for all traits except $\mathrm{NADH}$ and R-value. The muscle $\times$ treatment interaction was significant $(P<0.05)$ for glycogen content, $\mathrm{NAD}^{+}, \mathrm{pH}$, sarcomere length, and shear force. The treatment $\times$ time interaction was significant for $\mathrm{NAD}^{+}, \mathrm{pH}$, redox potential, and shear force. The three-way interaction of muscle $\times$ treatment $\times$ time was not significant for any trait $(P>0.05)$.

Because the main objective of this study was to evaluate the effect of injection on each of the three muscles, the means will be presented for the significant effects of the treatment $\times$ muscle and treatment $\times$ time interactions. Means for variables that only were significant for the main effect of treatments (WHC and L*, $a^{*}$ and $\left.b^{*}\right)$ are presented in Table 1.

\section{Treatment $\times$ Time Effects}

Across all muscles (Table 2), NaC was most effective in reducing shear force value (by $1.60 \mathrm{~kg}$ at d 3) compared to the control $(P<0.05)$. There was also a tendency for $\mathrm{CaCl}_{2}$ to reduce shear force $(P=0.08)$. How- ever, no treatment effects on shear force value were significant after $7 \mathrm{~d}$. This latter result was primarily because the control samples demonstrated a considerable degree of tenderization, much greater than that observed by any of the treatments. It is not clear if the degree of elevation in ionic strength provided by the treatments contributed to the inactivation of calpains (Huff-Lonergan and Lonergan, 1999) or if other mechanisms might be involved.

The $\mathrm{pH}$ values of treated muscles were higher at 24 and $72 \mathrm{~h}$ postmortem $(P<0.05)$ than the controls (Table 2 ). The $\mathrm{pH}$ declined in all muscles over time. The extent of the decline was reduced by glycolytic inhibitors $(\mathrm{NaC}$, $\mathrm{NaA}$, and $\mathrm{NaF}$ ). One goal of the research was to maintain an elevated $\mathrm{pH}$ without compromising color. Treated muscles had slightly (but not significantly) lower $a^{*}$ values for treated muscles (data not shown) compared to the control, suggesting a dilution effect due to the addition of the treatment solution.

Treated muscles showed higher reduction-oxidation potential and lower NAD content (higher oxidizing capacity) values than the control at $24 \mathrm{~h}$ postmortem; however, these differences were not significant by $72 \mathrm{~h}$ (Table 3 ). The decline in reducing capacity during storage appeared to occur more slowly in treated muscles than controls.

Reducing conditions (redox potential, $\mathrm{NAD}^{+}$and NADH content) were characterized among treatments because they are likely to affect color. For most muscles, glycolytic inhibitors $(\mathrm{NaA}, \mathrm{NaC}$, and $\mathrm{NaF})$ resulted in the highest $\mathrm{NAD}^{+}$concentrations $(P<0.05)$, but these differences were not of sufficient magnitude to be reflected in redox potential (data not shown). No differences were found in NADH content.

\section{Triceps Brachii Muscle}

All treatments resulted in higher $\mathrm{pH}$ values and glycogen contents than controls $(P<0.05)$; those containing $\mathrm{NaF}$ and $\mathrm{NaC}$ had the highest values for both traits (Table 4). These results provide clear evidence that postmortem glycolysis was inhibited. Sarcomeres were shorter with all treatments compared to the control. Despite muscle shortening, triceps brachii muscles treated with $\mathrm{NaC}$ and $\mathrm{CaCl}_{2}$ showed the lowest shear force values; however, they were not significantly different from the controls ( $P=0.080$ and 0.096 , respectively). It is also notable that there was a trend for treatment with $\mathrm{NaC}$ to result in lower shear force values than $\mathrm{CaCl}_{2}$. Samples treated with $\mathrm{NaA}$ had increased shear force values, and the $\mathrm{pH}$ was lower $(P<0.05)$ than samples containing $\mathrm{NaC}$ or NAF (Table 4 ).

\section{Supraspinatus Muscles}

Treated muscles had higher $\mathrm{pH}$ values than the control, with $\mathrm{NaF}$ and $\mathrm{NaC}$ having the highest $\mathrm{pH}(P<$ 0.05 ) values (5.93 and 6.18, respectively). These two treatments also had higher glycogen contents $(P<0.05)$. 
Table 2. Effect of the interaction treatment $\times$ time on $\mathrm{pH}$ and shear force $(\mathrm{n}=12)$

\begin{tabular}{lccccc}
\hline \hline & \multicolumn{2}{c}{$\mathrm{pH}$} & & \multicolumn{2}{c}{ Shear force, kg } \\
\cline { 2 - 3 } \cline { 5 - 6 } & $\begin{array}{c}24 \mathrm{~h} \\
\text { postmortem }\end{array}$ & $\begin{array}{c}72 \mathrm{~h} \\
\text { postmortem }\end{array}$ & & $\begin{array}{c}3 \mathrm{~d} \\
\text { postmortem }\end{array}$ & $\begin{array}{c}7 \mathrm{~d} \\
\text { postmortem }\end{array}$ \\
\hline Control $_{\text {Calcium chloride }}$ & $5.59^{\mathrm{eg}}$ & $5.33^{\mathrm{ef}}$ & & $6.37^{\mathrm{bg}}$ & $4.49^{\mathrm{cf}}$ \\
Sodium acetate & $5.82^{\mathrm{dg}}$ & $5.60^{\mathrm{df}}$ & & $5.46^{\mathrm{bcg}}$ & $4.89^{\mathrm{bcg}}$ \\
Sodium fluoride & $5.77^{\mathrm{dg}}$ & $5.49^{\mathrm{df}}$ & & $6.91^{\mathrm{bg}}$ & $6.17^{\mathrm{bg}}$ \\
Sodium citrate & $6.14^{\mathrm{bg}}$ & $6.02^{\mathrm{bf}}$ & & $6.20^{\mathrm{bg}}$ & $5.48^{\mathrm{bg}}$ \\
Standard deviation & $5.97^{\mathrm{cg}}$ & $5.76^{\mathrm{cf}}$ & & $4.78^{\mathrm{cg}}$ & $4.43^{\mathrm{cg}}$ \\
\hline
\end{tabular}

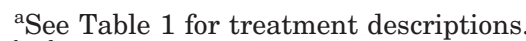

${ }_{\mathrm{b}, \mathrm{c}, \mathrm{d}, \mathrm{e}}$ Means bearing the same letters within a column are not significantly different $(P<0.05)$.

${ }^{\mathrm{f}, \mathrm{g}}$ Means for a trait bearing the same letters within a row are not significantly different $(P<0.05)$.

These results indicated that glycogen breakdown was delayed or inhibited. As expected, WHC increased in muscles with higher $\mathrm{pH}$, but these differences were not significant.

Sarcomere lengths of treated muscles were shorter than controls $(P<0.05)$ at $72 \mathrm{~h}$ postmortem. However, injections of $\mathrm{NaC}$ or $\mathrm{CaCl}_{2}$, in prerigor supraspinatus significantly reduced shear force values by 1.10 and $0.85 \mathrm{~kg}$, respectively, compared with the controls (Table 5).

Although not significant, $\mathrm{NaC}$ and $\mathrm{NaA}$ treatments were less red and yellow than the controls (data not shown). Treatments affected neither reducing potential nor NADH content; however, slight but significant differences in $\mathrm{NAD}^{+}$were detected in treated samples, which had a higher $\mathrm{NAD}^{+}$content than the controls (Table 5).

\section{Semimembranosus Muscles}

The fact that muscles treated with $\mathrm{NaF}$ or $\mathrm{NaC}$ had elevated $\mathrm{pH}$ values and greater glycogen content than the controls indicates that postmortem glycolysis rate decreased due to injection of inhibitors (Table 6).

All treated samples had shorter sarcomeres than the control at $72 \mathrm{~h}$ postmortem (Table 6 ). The shortest sarcomere length was observed in samples injected with

Table 3. Effect of the interaction treatment $\times$ time on $\mathrm{pH}$ and shear force $(\mathrm{n}=12)$

\begin{tabular}{lccccc}
\hline \hline & \multicolumn{2}{c}{ Redox potential, $\mathrm{mV}$} & & \multicolumn{2}{c}{$\mathrm{NAD}^{+}, \mu \mathrm{mol} / \mathrm{g}$ tissue } \\
\cline { 2 - 3 } \cline { 5 - 6 } Treatment & $24 \mathrm{~h}$ & $72 \mathrm{~h}$ & & $24 \mathrm{~h}$ & $72 \mathrm{~h}$ \\
\hline Control & $120^{\text {ce }}$ & $136^{\text {bd }}$ & & $0.010^{\text {ce }}$ & $0.066^{\text {ce }}$ \\
Calcium chloride & $127^{\text {bce }}$ & $130^{\text {be }}$ & & $0.216^{\text {be }}$ & $0.100^{\text {bce }}$ \\
Sodium acetate & $132^{\text {be }}$ & $140^{\text {bd }}$ & & $0.289^{\text {be }}$ & $0.144^{\text {bd }}$ \\
Sodium fluoride & $129^{\text {bce }}$ & $137^{\text {bd }}$ & & $0.251^{\text {be }}$ & $0.090^{\text {cd }}$ \\
Sodium citrate & $125^{\text {bce }}$ & $132^{\text {bd }}$ & & $0.256^{\text {be }}$ & $0.143^{\text {bd }}$ \\
Standard deviation & 2.3 & 2.3 & & 0.01 & 0.01 \\
\hline
\end{tabular}

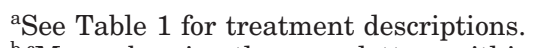

b,c Means bearing the same letters within a column are not significantly different $(P<0.05)$.

${ }_{\mathrm{d}, \mathrm{e}}$ Means for a trait bearing the same letters within a row are not significantly different $(P<0.05)$.
}

$\mathrm{CaCl}_{2}(1.50 \mu \mathrm{m})$ and $\mathrm{NaF}(1.52 \mu \mathrm{m})$. The tenderizing effect of $\mathrm{NaF}$ and $\mathrm{NaC}$ found in supraspinatus and triceps brachii was also observed in semimembranosus. Treatment with $\mathrm{NaC}$ reduced shear force by $0.9 \mathrm{~kg}$ compared with the control $(P=0.06)$.

Treated samples lost reducing capacity (higher $\mathrm{mV}$ values) over time ( $P>0.05$; data not shown). They also had significantly higher $\mathrm{NAD}^{+}$contents than the controls (Table 6). It was noticed that $\mathrm{NaA}$ produced the highest $\mathrm{NAD}^{+}$content $(P<0.05)$.

\section{Discussion}

High $\mathrm{pH}$ has been associated with increased tenderness (Harrell et al., 1978; Watanabe et al., 1996). Calkins et al. (1999) identified several potential glycolytic inhibitors, and found that inhibition of glycolysis may improve tenderness by minimizing $\mathrm{pH}$ decline. Results from this study indicate that postmortem glycolysis was inhibited in muscles injected with $\mathrm{NaC}$ or $\mathrm{NaF}$, resulting in higher $\mathrm{pH}$ and greater glycogen content than the controls.

It is well documented that prerigor muscles are susceptible to shortening (Boles and Swan, 1997). Wheeler et al. (1991) reported that hot boning had no effect on shear force. All treated muscles in this study had shorter sarcomeres than the controls at $72 \mathrm{~h}$ postmor-

Table 4. Effect of prerigor injection on meat traits of triceps brachii beef muscles $(n=8)$

\begin{tabular}{lcccccc}
\hline \hline & \multicolumn{5}{c}{ Treatment $^{\mathrm{a}}$} \\
\cline { 2 - 6 } Variable & Control & $\begin{array}{c}\text { Calcium } \\
\text { chloride }\end{array}$ & $\begin{array}{c}\text { Sodium } \\
\text { acetate }\end{array}$ & $\begin{array}{c}\text { Sodium } \\
\text { fluoride }\end{array}$ & $\begin{array}{c}\text { Sodium } \\
\text { citrate }\end{array}$ & SE \\
\hline Shear force, kg & $4.79^{\mathrm{e}}$ & $4.77^{\mathrm{e}}$ & $6.14^{\mathrm{d}}$ & $5.42^{\mathrm{de}}$ & $4.30^{\mathrm{e}}$ & 0.31 \\
pH & $5.48^{\mathrm{g}}$ & $5.75^{\mathrm{ef}}$ & $5.63^{\mathrm{f}}$ & $6.03^{\mathrm{d}}$ & $5.83^{\mathrm{e}}$ & 0.03 \\
Glycogen & $25.20^{\mathrm{e}}$ & $27.90^{\mathrm{e}}$ & $26.56^{\mathrm{e}}$ & $40.67^{\mathrm{d}}$ & $31.19^{\mathrm{de}}$ & 2.45 \\
NAD $^{+\mathrm{b}}$ & $0.074^{\mathrm{e}}$ & $0.147^{\mathrm{de}}$ & $0.196^{\mathrm{d}}$ & $0.184^{\mathrm{d}}$ & $0.211^{\mathrm{d}}$ & 0.01 \\
SL $^{\mathrm{c}}$ & $2.37^{\mathrm{d}}$ & $1.33^{\mathrm{e}}$ & $1.55^{\mathrm{e}}$ & $1.38^{\mathrm{e}}$ & $1.61^{\mathrm{e}}$ & 0.09 \\
\hline
\end{tabular}

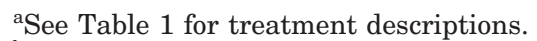

${ }^{\mathrm{b}} \mathrm{In} \mu \mathrm{mol} / \mathrm{g}$ of muscle.

${ }^{\mathrm{c}}$ Sarcomere length $(\mu \mathrm{m})$.

d,e,f,g Means bearing the same letters within a row are not significantly different $(P<0.05)$. 
Table 5. Effect of prerigor injection on meat traits of supraspinatus beef muscles $(n=8)$

\begin{tabular}{lcccccr}
\hline \hline & \multicolumn{5}{c}{ Treatment $^{\mathrm{a}}$} \\
\cline { 2 - 5 } Variable & Control & $\begin{array}{c}\text { Calcium } \\
\text { chloride }\end{array}$ & $\begin{array}{c}\text { Sodium } \\
\text { acetate }\end{array}$ & $\begin{array}{c}\text { Sodium } \\
\text { fluoride }\end{array}$ & $\begin{array}{c}\text { Sodium } \\
\text { citrate }\end{array}$ & SE \\
\hline Shear force, $\mathrm{kg}$ & $5.92^{\mathrm{e}}$ & $5.07^{\mathrm{f}}$ & $7.34^{\mathrm{d}}$ & $5.87^{\mathrm{f}}$ & $4.82^{\mathrm{f}}$ & 0.30 \\
$\mathrm{pH}$ & $5.33^{\mathrm{g}}$ & $5.70^{\mathrm{f}}$ & $5.73^{\mathrm{f}}$ & $6.18^{\mathrm{d}}$ & $5.93^{\mathrm{e}}$ & 0.03 \\
Glycogen & $21.37^{\mathrm{e}}$ & $24.16^{\mathrm{e}}$ & $19.20^{\mathrm{e}}$ & $34.13^{\mathrm{d}}$ & $27.45^{\mathrm{de}}$ & 2.45 \\
$\mathrm{NAD}^{+\mathrm{b}}$ & $0.074^{\mathrm{e}}$ & $0.114^{\mathrm{de}}$ & $0.158^{\mathrm{d}}$ & $0.145^{\mathrm{de}}$ & $0.127^{\mathrm{de}}$ & 0.01 \\
$\mathrm{SL}^{\mathrm{c}}$ & $2.12^{\mathrm{d}}$ & $1.28^{\mathrm{e}}$ & $1.44^{\mathrm{e}}$ & $1.54^{\mathrm{e}}$ & $1.51^{\mathrm{e}}$ & 0.10 \\
\hline
\end{tabular}

asee Table 1 for treatment descriptions.

${ }^{\mathrm{b}} \mathrm{In} \mu \mathrm{mol} / \mathrm{g}$ muscle.

'Sarcomere length $(\mu \mathrm{m})$.

d,e,f,g Means bearing the same letters within a row are not significantly different $(P<0.05)$

tem. It was not possible to determine if this shortening was a consequence of the treatment compounds themselves or because treated muscles were removed from muscle restraint prior to development of rigor. Perhaps the improvement in tenderness would be higher if sarcomere shortening had been minimized. Despite muscle shortening, injection of the glycolytic inhibitor $\mathrm{NaC}$ reduced shear force values in semimembranosus and supraspinatus muscles. Although the trend was present in the triceps brachii muscle, the treatment effect was not significant. The tenderizing effect of $\mathrm{NaC}$ was comparable to $\mathrm{CaCl}_{2}$.

The most significant improvement in tenderness was observed after $3 \mathrm{~d}$ of aging. Treatment effects on shear force value were not significant after $7 \mathrm{~d}$; therefore, the effect of aging on tenderness of treated muscles was minimized. Wheeler et al. (1991) reported that application of $\mathrm{CaCl}_{2}$ to prerigor muscles resulted in a rapid tenderization that was complete within $1 \mathrm{~d}$ postmortem. Application of $\mathrm{CaCl}_{2}$ to prerigor (Koohmaraie et al., 1988; Wheeler et al., 1991) and postrigor muscles (Wheeler et al., 1992;) has resulted in rapid tenderization. Tenderness is due to the increased calpain protease activity caused by the increase in calcium ion concentration (Koohmaraie et al., 1990).

Alvarez (1996) found that marinating prerigor obliquus abdominis externus and obliquus abdominis in-

Table 6. Effect of prerigor injection on meat traits of semimembranosus beef muscles $(n=8)$

\begin{tabular}{|c|c|c|c|c|c|c|}
\hline \multirow[b]{2}{*}{ Variable } & \multicolumn{5}{|c|}{ Treatment $^{\mathrm{a}}$} & \multirow[b]{2}{*}{$\mathrm{SE}$} \\
\hline & Control & $\begin{array}{l}\text { Calcium } \\
\text { chloride }\end{array}$ & $\begin{array}{l}\text { Sodium } \\
\text { acetate }\end{array}$ & $\begin{array}{l}\text { Sodium } \\
\text { fluoride }\end{array}$ & $\begin{array}{c}\text { Sodium } \\
\text { citrate }\end{array}$ & \\
\hline Shear force, $\mathrm{kg}$ & $5.58^{\mathrm{de}}$ & $5.68^{\mathrm{de}}$ & $6.13^{\mathrm{d}}$ & $6.22^{\mathrm{d}}$ & $4.70^{\mathrm{e}}$ & 0.30 \\
\hline $\mathrm{pH}$ & $5.40^{\mathrm{g}}$ & $5.68^{\mathrm{ef}}$ & $5.53^{\mathrm{fg}}$ & $6.04^{\mathrm{d}}$ & $5.85^{\mathrm{f}}$ & 0.03 \\
\hline Glycogen ${ }^{b}$ & $32.90^{\mathrm{d}}$ & $42.64^{\mathrm{de}}$ & $32.92^{\mathrm{d}}$ & $48.83^{\mathrm{e}}$ & $50.38^{\mathrm{e}}$ & 2.48 \\
\hline $\mathrm{NAD}^{+\mathrm{b}}$ & $0.105^{\mathrm{e}}$ & $0.213^{\mathrm{d}}$ & $0.296^{\mathrm{d}}$ & $0.186^{\mathrm{de}}$ & $0.244^{\mathrm{d}}$ & 0.01 \\
\hline $\mathrm{SL}^{\mathrm{c}}$ & $1.75^{\mathrm{d}}$ & $1.50^{\mathrm{e}}$ & $1.71^{\mathrm{d}}$ & $1.52^{\mathrm{e}}$ & $1.71^{\mathrm{d}}$ & 0.09 \\
\hline
\end{tabular}

${ }^{\text {a See Table }} 1$ for treatment descriptions.

${ }^{\mathrm{b}} \mathrm{In} \mu \mathrm{mol} / \mathrm{g}$ muscle.

${ }^{\mathrm{c}}$ Sarcomere length $(\mu \mathrm{m})$.

$\mathrm{d}, \mathrm{e}, \mathrm{f}, \mathrm{g}$ Means bearing the same letters within a row are not significantly different at $(P<0.05)$. ternus beef muscles with NaF improved tenderness. Martin-Herrrera (1998) reported similar results in sternomandibularis muscles marinated with $\mathrm{NaF}$; however, this improvement was not observed in rectus abdominis muscle.

The improvement in tenderness found in higher $\mathrm{pH}$ muscles indicates a strong relationship between high $\mathrm{pH}$ and tenderness. A likely explanation is that high $\mathrm{pH}$ increases calpain activity (Yu and Lee, 1986; Beltrán et al., 1997), which greatly enhances tenderization. Injection with glycolytic inhibitors could also affect other factors such as ionic strength. Wu and Smith (1987) stated that the increase of ionic strength decreased actin-myosin interactions, inducing protein solubilization. The gradual increase of ionic strength during postmortem storage might contribute to postmortem tenderization. However, other authors (Huff-Lonergan and Lonergan, 1999) stated that high ionic strength reduces calpain activity. The results of this study seem to indicate that acceleration of postmortem tenderization due to prerigor injection is not the result of an increase in ionic strength alone, because not all solutions improved tenderness, even though they all contributed to ionic strength. The observed tenderization might be due to an activation of the calpain system or a synergistic action of ionic strength with enzymatic proteolysis for some compounds; others (such as $\mathrm{NaA}$ ) may actually inhibit calpain activity.

The $\mathrm{R}$-value is the ratio of hypoxanthine to nucleotide concentrations, which indicates the state of rigor mortis (Honikel and Fischer, 1977). No differences were detected in R-values at any sampling periods, indicating that after $24 \mathrm{~h}$, all muscles were in similar stages of rigor. From these data, it was not possible to determine if any treatment entered rigor in advance of the control.

Injection with NaA did not improve tenderness. Muscles treated with $\mathrm{NaA}$ were always less tender than the control at any period of aging. The fact that shear force value did not decrease during aging suggests that this compound may inhibit proteolysis.

Muscle $\mathrm{pH}$ is one of the principal factors affecting WHC; high $\mathrm{pH}$ is directly related to high WHC. Among the glycolytic inhibitors tested in this study, $\mathrm{NaF}$ was the compound that produced the highest $\mathrm{pH}$ in all mus- 
cles, and increased WHC. However, the effect of treatment on WHC was not significant compared within muscles. Perhaps the addition of $10 \%$ solution obscured the effect of $\mathrm{pH}$ on WHC when comparing within muscle. Hamm (1986) stated that NaC improves WHC by sequestering bivalent cations $\left(\mathrm{Ca}^{2+}\right.$ and $\mathrm{Mg}^{2+}$ ions) that decrease the WHC of muscle. However, not all compounds that have a sequestering effect on bivalent cations improve the WHC of meat (Hamm, 1986). MartinHerrera (1998) found an increase in WHC in flank muscles marinated with $\mathrm{NaF}$ and a decrease in WHC with $\mathrm{CaCl}_{2}$.

To better understand color development in muscles treated with glycolytic inhibitors, oxidation-reduction potential, and $\mathrm{NAD}^{+} / \mathrm{NADH}$ content were investigated. Oxidation-reduction potential in meat may be influenced by the addition of exogenous compounds (Rödel and Sheuer, 1999) and also may cause color alterations in fresh meat. However, limited information exists regarding the oxidation-reduction potential of meat and its significance to lean color. Renerre and Labas (1987) stated that muscles with the most unstable color showed high reducing activities.

In this study, oxidation-reduction potential in all muscles increased during storage (higher oxidizing capacity). Contrary to our results, Ahn and Maurer (1989) found that under normal conditions, oxidation-reduction potential in meat decreases during postmortem storage.

Muscle $\mathrm{NAD}^{+} / \mathrm{NADH}$ metabolism is also related to the reduction process, color, and glycolysis. During glycolysis, $\mathrm{NAD}^{+}$is reduced during the oxidation of glyceraldehyde 3-phosphate to 1,3 bisphosphoglycerate, and $\mathrm{NADH}$ is oxidized to $\mathrm{NAD}^{+}$during the reduction of pyruvate to lactate. The inhibition of glycolysis postmortem would be expected to alter $\mathrm{NAD}^{+}$and $\mathrm{NADH}$ content according to where inhibition is occurring within the glycolytic pathway. We hypothesized that inhibition of enolase by $\mathrm{NaF}$ might provoke a final reduced state (low $\mathrm{NAD}^{+}: \mathrm{NADH}$ ratio). Results from this study do not support this hypothesis. Faustman and Cassens (1991) found that the gluteus medius muscle contained less $\mathrm{NAD}^{+}$and was less color-stable than longissimus muscle. In this study, control samples had less $\mathrm{NAD}^{+}$content than treated samples, although differences in color were not significant.

The tendency for less intense red color in injected samples likely reflects a brine injection effect. Adding fluid to muscles produces a watery surface that can scatter light, making the sample appear lighter. The solution also dilutes myoglobin concentration. However, glycolytic inhibitors may have induced chemical changes in muscle that altered color chemistry. MartinHerrera (1998) found that flank muscles marinated with calcium fluoride or $\mathrm{NaF}$ were less red than noninjected muscles. Wheeler et al. (1994) reported that addition of $\mathrm{CaCl}_{2}$ had no effect on lean color through $3 \mathrm{~d}$ of retail display. In this study, $\mathrm{CaCl}_{2}$ treated muscles had lower a* values (less red color) than controls. Atkinson et al. (1969) stated that high NADH concentrations increased the rate of oxygen uptake, improving color stability. Treated muscles from this study had more NADH than the controls. This seems to be a favorable condition to improve color in muscles injected with glycolytic inhibitors, although color stability during retail display was not evaluated.

Fiber type composition in each muscle may explain some differences observed in $\mathrm{pH}$, glycogen content, sarcomere shortening, and $\mathrm{NAD}^{+}$content. Semimembranosus muscles, which have a higher proportion of white fibers (Talmant and Monin, 1986), had higher content of glycogen, lower $\mathrm{pH}$, more active glycolytic metabolism, shorter sarcomeres, and higher $\mathrm{NAD}^{+}$content than supraspinatus or triceps brachii, which have a high proportion of red fibers (Cornforth et al., 1980). The differences in postmortem glycolysis due to fiber type composition may be partly responsible for the variation of tenderness and color among muscles in this study.

\section{Implications}

The opportunity exists to enhance the value of lowquality beef muscles. Sodium citrate and sodium fluoride were successful in improving beef tenderness by maintaining a high $\mathrm{pH}$ with no significant alteration to lean color. Aging did not produce an additive effect on tenderness. The most significant tenderness improvement was observed after $3 \mathrm{~d}$. Further studies are needed to understand the process that affects color development and meat tenderness during glycolytic inhibition.

\section{Literature Cited}

Ahn, D. U., and A. J. Maurer. 1989. Effects of added pigments, salt and phosphate on color, extractable pigment, total pigment and oxidation-reduction potential in turkey breast meat. Poult. Sci. 68:1088-1099.

Alvarez, J. 1996. Evaluación del efecto de la aplicación de cloruro de calcio y fluoruro de sodio en los músculos oblicuos abdominis internus y externus antes del rigor mortis. MS Thesis, ITESM, Monterrey, México.

AMSA.1995. Research guidelines for cookery, sensory evaluation and instrumental tenderness measurements of fresh meat. Am. Meat Science Assoc., Chicago, IL.

Atkinson, J. L., M. J. Follett, and P.W. Ratcliff. 1969. Postmortem changes in the oxygen uptake and NAD content of lamb semimembranosus. Nature (Lond.) 223:1372-1373.

Beltrán, J. A., I. Jaime, P. Santolaria, C. Sañudo, P. Albertí, and P. Roncalés. 1997. Effect of stress-induced high postmortem $\mathrm{pH}$ on protease activity and tenderness of beef. Meat Sci. 45:201-207.

Boles, J. A., and J. E. Swan. 1997. Effects of brine ingredients and temperature on cook yields and tenderness of prerigor processed roast beef. Meat Sci. 45:87-97.

Brooks, J. C., J. B. Belew, D. B. Griffin, B. L. Gwartney, D. S. Hale, W. R. Henning, D. D. Johnson, J. B. Morgan, F. C. Parrish, Jr., J. O. Reagan, and J. W. Savell. 2000. National Beef Tenderness Survey-1998. J. Anim. Sci. 78:1852-1860.

Calkins, C. R., N. Jerez, and J. Velazco. 1999. Glycolytic inhibition in prerigor muscle: An alternative method to improve beef tenderness. Pages 72-74 in Nebraska Beef Rep., Univ. of Nebraska, Lincoln. 
Cornforth, D. P., A. L. Hecker, D. A. Cramer, A. A. Spindler, and M. M. Mathias. 1980. Maturity and its relationship to muscle characteristics of cattle. J. Anim. Sci. 50:75-80.

Cross, H. R., R. L. West, and T. R. Dutson. 1981. Comparison of methods for measuring sarcomere length in beef semitendinosus muscle. Meat Sci. 5:261-266.

Dalrymple, R. H., and R. Hamm. 1973. A method for the extraction of glycogen and metabolites from a single muscle sample. J. Food Technol. 8:439-444.

Faustman, C., and R. G. Cassens. 1991. The effect of cattle breed and muscle type on discoloration and various biochemical parameters in fresh beef. J. Anim. Sci. 69:184-193.

Hamm, R. 1986. Functional properties of the myofibrillar system and their measurements. Pages 135-136 in Muscle as Food. P. J. Bechtel, ed. Academic Press, Orlando, FL.

Harrell, R. A., T. D. Bidner, and E. A. Icaza. 1978. Effect of altered muscle $\mathrm{pH}$ on beef tenderness. J. Anim. Sci. 46:1592-1596.

Honikel, K. O., and C. Fischer. 1977. A rapid method for the detection of PSE and DFD porcine muscles. J. Food Sci. 42:1633-1636.

Huff-Lonergan, E., and S. M. Lonergan. 1999. Postmortem mechanisms of meat tenderization. The roles of the structural proteins and the calpain system. Pages 229-251 in Quality Attributes of Muscle Foods. Y. L. Xiong, C. T. Ho, and F. Shahidi, ed. Kluwer Academic/Plenum Publishers, New York.

Jauregui, C. A., J. M. Regenstein, and R. C. Baker. 1981. A simple centrifugal method for measuring expressible moisture, a waterbinding property of muscle foods. J. Food Sci. 46:1271-1273.

Jeremiah, L. E., A. K. W. Tonh, and L. L. Gibson. 1991. The usefulness of muscle color and $\mathrm{pH}$ for segregating beef carcasses into tenderness groups. Meat Sci. 30:97-114.

Klingenberg, M. 1985. Nicotinamide-adenine dinucleotides and dinucleotide phosphate. Pages 251-278 in Methods of Enzymatic Analysis. 3rd ed., vol. 7. H. V. Bergmeyer, ed. Verlag Chemie. Deerfield Beach, FL.

Koohmaraie, M., A. S. Babiker, A. L. Schroeder, R. A. Merkel, and T. R. Dutson. 1988. Acceleration of postmortem tenderization in ovine carcasses through activation of $\mathrm{Ca}^{+2}$-dependent proteases. J. Food Sci. 53:1638-1641.

Koohmaraie, M., G. Whipple, and J. D. Crouse. 1990. Acceleration of postmortem tenderization in lamb and Brahman-cross beef carcasses through infusion of calcium chloride. J. Anim. Sci. 68:1278-1283.

Martin-Herrera, I. 1998. Effect of prerigor marination using calcium chloride, calcium, or sodium fluoride on shear force and quality traits of excised beef rectus abdominis and sternomandibularis muscles. MS Thesis, Kansas State Univ., Manhattan.

Renerre, M., and R. Labas. 1987. Biochemical factors influencing metmyoglobin formation in beef muscles. Meat Sci. 19:151-165.

Rödel, W., and R. Scheuer. 1999. Redox potential of meat and meat products. 1. Physico-chemical basis, determination and evaluation of the redox potential. Fleischwirtschaft Int. 1:38-41.

Roehrig, K. L., and J. B. Allred. 1974. Direct enzymatic procedure for the determination of liver glycogen. Anal. Biochem. 58:414-421.

Steel, R. G. D., and J. H. Torrie. 1980. Principles and Procedures of Statistics, 2nd ed. McGraw-Hill Book Company, New York.

Talmant, A., and G. Monin. 1986. Activities of metabolic contractile enzymes in 18 bovine muscles. Meat Sci. 18:23-40.

Watanabe, A., C. C. Daly, and C. E. Devine. 1996. The effects of the ultimate $\mathrm{pH}$ of meat on tenderness changes during aging. Meat Sci. 42:67-78.

Wheeler, T. L., M. Koohmaraie and J. D. Crouse. 1991. Effects of calcium chloride injection and hot boning on the tenderness of round muscles. J. Anim. Sci. 69:4871-4875.

Wheeler, T. L., J. D. Crouse, and M. Koohmaraie. 1992. The effect of postmortem time of injection and freezing on the effectiveness of calcium chloride for improving beef tenderness. J. Anim. Sci. 70:3451-3457.

Wheeler, T. L., M. Koohmaraie, and S. D. Schackelford. 1994. Reducing inconsistent beef tenderness with calcium-activated tenderization. Pages 199-121 in Proc. Meat Industry Res. Conf., San Francisco, CA.

Wu, F., and S. B. Smith. 1987. Ionic strength and myofibrillar protein solubilization. J. Anim. Sci. 65:597-608.

Wulf, D. M., S. F. O'Connor, J. D. Tatum, and G. C. Smith. 1997. Using objective measures of muscle color to predict beef longissimus tenderness. J. Anim. Sci. 75:684-692.

Yu, L. P., and Y. B. Lee. 1986. Effects of postmortem $\mathrm{pH}$ and temperature on bovine muscle structure and meat tenderness. J. Food Sci. 51:774-780. 